\title{
Effects of Juglone on the Antioxidant Metabolism in the Larval Hemolymph of the Greater Wax Moth Galleria mellonella L. (Lepidoptera: Pyralidae)
}

\author{
Emine DUMAN ERBAŞ ${ }^{1 *}$, Hülya ALTUNTAŞ ${ }^{2}$
}

\begin{abstract}
Reducing the usage of chemical pesticides used to control pests in agriculture and stored products is an important phenomenon. Also, eco-friendly biopesticides have become highly important for use in the management of the pest control programs to overcome the negative influences of other synthetic chemicals. In this study oxidative stress changes induced by one important phytochemical compound, juglone, in Galleria mellonella larvae were investigated. For this purpose, effective concentrations $\left(\mathrm{LC}_{10}: 0.5 \mathrm{mg}\right.$; $\mathrm{LC}_{30}: 1.5 \mathrm{mg} ; \mathrm{LC}_{50}: 2.3 \mathrm{mg}$ ) of juglone were added into the $2 \mathrm{~g}$ diet of the first instar larvae. Hemolymph samples from the last instar larvae were used to analyses of antioxidant enzyme activity (glutathione peroxidases - GPx, glutathione-S transferase - GST, catalase - CAT, and superoxide dismutase - SOD) and malondialdehyde (MDA) assays. Activities of antioxidant enzymes (SOD, CAT, and GST) and MDA level in the hemolymph of last instar G. mellonella larvae exposed to dietary juglone changed dose-dependently when compared to the control larvae. However, there was no change detected in GPx enzyme activity in both treated and untreated larvae. Consequently, effective doses of juglone are toxic to the model and pest insect G. mellonella.
\end{abstract}

Keywords: Antioxidant Metabolism, Galleria mellonella, Hemolymph, Juglone.

\section{Juglonun Büyük Balmumu Güvesi Galleria mellonella L. (Lepidoptera: Pyrelidae)'nın Larval Hemolenfinde Antioksidan Metabolizma Üzerine Etkileri}

$\ddot{O} z$

Tarımsal alanlarda ve depolanan ürünlerde zararlı böcekler ile mücadele amacıyla kullanılan kimyasal pestisitlerin uygulamalarının azaltılması önemli bir olgudur. Bununla birlikte, çevre dostu biyopestisitler zararlı kontrol programlarının yönetiminde diğer sentetik kimyasalların olumsuz etkilerinin üstesinden gelmek için önemli hale gelmiştir. Bu çalışmada, önemli bir fitokimyasal bileşik olan Juglonun Galleria mellonella larvalarında neden olduğu oksidatif stres değişiklikleri incelenmiş̧tir. $\mathrm{Bu}$ amaçla, juglonun etkili konsantrasyonları $\left(\mathrm{LC}_{10}: 0.5 \mathrm{mg} ; \mathrm{LC}_{30}: 1.5 \mathrm{mg}\right.$; $\mathrm{LC}_{50}: 2.3 \mathrm{mg}$ ) birinci evre larvaların 2 gram besini içerisine ilave edildi. Son dönem larvaların hemolenf örnekleri, antioksidan enzim aktivitesi (glutatyon peroksidazlar - GPx, glutatyon-S transferaz - GST, katalaz - CAT ve süperoksit dismutaz - SOD) ve malondialdehit (MDA) testlerinin analizlerinde kullanıldı. Besinsel juglona maruz kalan son dönem G. mellonella larvalarının hemolenfinde antioksidan enzim aktiviteleri (SOD, CAT ve GST) ve MDA miktarı kontrol larvalarıyla karşılaştırıldığında doza bağlı olarak değişmiş̧ir. Bununla birlikte, uygulama yapılan ve yapılmayan larvalara ait GPx enzim aktivitesinde değişiklik belirlenmedi. Sonuç olarak, juglonun etkili dozları model ve zararlı böcek $G$. mellonella için toksiktir.

Anahtar Kelimeler: Antioksidan Metabolizma, Galleria mellonella, Hemolenf, Juglon.

1Karadeniz Technical University, Faculty of Science, Department of Biology, Trabzon, Turkey...eduman09@gmail.com
${ }^{2}$ Eskişehir Technical University, Faculty of Science, Department of Biology, Eskişehir, Turkey hyalcitas@eskisehir.edu.tr

${ }^{1}$ https://orcid.org/0000-0003-4975-1182 ${ }^{2}$ https://orcid.org/0000-0003-4505-0098 


\section{Introduction}

Due to the adverse effects of synthetic chemicals on the biodiversity in the ecosystems, plantbased chemicals, known as eco-friendly biopesticides, are gaining more importance for use in integrated pest management (IPM) programs. Evidence from previous studies has shown that various plant secondary compounds and plant extracts have toxic effects on some insects, causing significant changes in, morphology, sexual maturity, egg hatching ratio and developmental abilities as well as feeding behaviour (Emam et al., 2009; Jeyasankar et al., 2010; Rattan and Sharma, 2011; Şeref-Gün et al., 2011; Paul and Sohkhlet, 2012; Duman-Erbaş and Altuntaş, 2020). Like several phytochemicals, juglone (5-hydroxy-1,4-naphthoquinone) is also an important plant secondary compound, synthesized by walnut species, recommended for use as a biopesticide (Babula et al., 2009; Islam and Widhalm, 2020). Previous studies showed that juglone has an antifeedant potential and adversely affects the survival and reproductive activities of different insect species such as model insect G. mellonella (Sun et al., 2007; Sorokin and Whitaker, 2008; Piskorski et al., 2011; Akhtar et al., 2012; Cespedes et al., 2016; Altuntaş et al., 2020; Duman-Erbaş and Altuntaş, 2020). These significant changes in insect development and biological activities indicate that dietary juglone is potentially toxic on insects by altering antioxidant response and lipid peroxidation in the insect hemolymph. Storage proteins and metabolic enzymes found in insect hemolymph synthesized from adipose tissue, midgut, or other tissues. Besides, it is known that sublethal concentrations of several chemicals can induce detoxification processes that are carried out by antioxidant enzymes in insect hemolymph and fat body (Krishnan and Kodrik, 2006; Büyükgüzel et al., 2010; Büyükgüzel et al., 2013; Altuntaş et al., 2016; Sezer-Tuncsoy et al., 2019). Therefore, changes in the hemolymph should be analysed to examine the physiological effects of juglone. For this purpose, the physiological stress that occurs in the larval hemolymph depending on Juglone treatment was investigated in our study.

It has been reported that several plant allelochemicals including Juglone increase or decrease the activity of the detoxification enzyme, GST (Lee, 1991; Wheeler et al., 1993; Thiboldeaux et al., 1994; Yu and Abo-Elghar, 2000; Yu and Huang, 2000; Altuntas et al., 2020). Furthermore, Altuntaş et al. (2020) showed that dietary Juglone induces lipid peroxidation and genotoxicity in the total larval tissue of $G$. mellonella depending on the concentration.

In the present study, the larval stage of Galleria mellonella L. (Lepidoptera) was selected as both the model insect and storage pest species to test the influences of dietary juglone on the antioxidant and oxidant metabolism in the hemolymph. 


\section{Materials and Methods}

\subsection{Insect}

Larval stage of G. mellonella were obtained from stock culture using semi-artificial diet as indicated by Duman-Erbaş and Altuntaş (2020). G. mellonella were kept in an insectarium at $28 \pm 1$ ${ }^{\circ} \mathrm{C}, 60 \pm 5 \% \mathrm{RH}$ in the constant darkness conditions at Eskisehir Technical University, Turkey.

\subsection{Bioassays and Homogenization}

To evaluate the oxidative acts of juglone on the larval hemolymph of G. mellonella, effective concentrations of juglone, which are reported by Duman-Erbaş and Altuntaş (2020) (LC $\mathrm{L}_{10}: 0.5 \mathrm{mg}$, $\mathrm{LC}_{30}: 1.5 \mathrm{mg}, \mathrm{LC}_{50}: 2.3 \mathrm{mg} / 2 \mathrm{~g}$ larval diet) were used for all experiments. The LCx of juglone were mixed into the artificial diet of the first stage larva of $G$. mellonella and each larva fed up to the seventh instar $(0.18 \pm 0.02 \mathrm{~g})$. All larvae were raised under insectarium conditions. For each control and experimental group, all experiments were performed with 20 larvae randomized from different populations at different times in three repetitions. For each analysis, hemolymph (10 $\mu$ from each individual larva) was collected and transferred into microcentrifuge tubes $(0.5 \mathrm{ml})$ containing cold homogenization buffer (v/v; $1.15 \% \mathrm{w} / \mathrm{v} \mathrm{KCl}, 25 \mathrm{mM} \mathrm{K}_{2} \mathrm{HPO}_{4}, 2 \mathrm{mM}$ DDT, $5 \mathrm{mM}$ EDTA, $2 \mathrm{mM}$ PMSF, pH 7.0, Sigma), and $1 \mu \mathrm{g}$ melanization inhibitor (phenylthiourea, Sigma) for antioxidant enzymes activity assays (Altuntaş, 2015a). Hemolymph samples from 20 larvae in each replicate of the biochemical assay were transferred into the same Eppendorf tube and centrifuged at 10,000 g, +4 ${ }^{\circ} \mathrm{C}$ for $15 \mathrm{~min}$ for homogenization. After this, the supernatant was extracted and used in enzyme activities and protein amount analyses. On the other hand, to analysis of the level of MDA as a lipid peroxidation marker in larval hemolymph, samples were collected as mentioned above into a cold 1.5 $\mathrm{ml}$ Eppendorf tube including homogenization buffer, centrifuged at $700 \mathrm{~g},+4{ }^{\circ} \mathrm{C}$ for $10 \mathrm{~min}$.

\subsection{Assay of Enzyme Activities and Malondialdehyde Amount}

Analysis of the activities of SOD, GST, GPX, and MDA amount was carried out using commercial kits developed by Cayman Chemical. The absorbance of the samples using xanthine and xanthine oxidase systems were measured at $450 \mathrm{~nm}$, and thus SOD activity presented in the larval hemolymph was defined as $\mathrm{U} / \mathrm{mg}$ protein.

To test the activity of total GST enzyme, increased absorbance resulting from conjugation of CDNB (1-chloro-2, 4 dinitrobenzene) and GSH (glutathione) with GST enzyme were measured 
kinetically at $340 \mathrm{~nm}$ for 5 minutes. The specific GST activity was calculated using $0.00503 \mu \mathrm{M}^{-1}$ as the extinction coefficient.

In determining the GPx enzyme activity, kinetic measurement was performed at $340 \mathrm{~nm}$ for 5 minutes based on the measurement of the oxidation rate of NADPH (nicotinamide adenine dinucleotide phosphate). This specific enzyme activity was defined as nmol/min/mg protein.

In the measurement of the lipid peroxidation level in larval hemolymph, acidic reaction products between thiobarbituric acid (TBA) and MDA at $95{ }^{\circ} \mathrm{C}$ were measured at $530 \mathrm{~nm}$. After analysis, the amount of MDA was calculated as nmol / mg protein (extinction coefficient.: $1.56 \times 105$ $\left.\mathrm{M}^{-1} \mathrm{~cm}^{-1}\right)$.

The CAT enzyme analysis was carried out by manual experiment according to Chance and Maehly, 1955. For this purpose, the amount of hydrogen peroxide decreased as a result of CAT enzyme activity was measured kinetically for 3 minutes at $240 \mathrm{~nm}$. The specific enzyme activity was calculated as $\mathrm{U} / \mathrm{mg}$ protein (extinction coefficient is e240 $=0.0394 \mathrm{mM}^{-1} \mathrm{~cm}^{-1}$ ).

These enzyme measurements were read on a microtiter plate (BIO-TEK Brand EPOCH). Protein concentrations used in MDA and enzyme activity assays were detected using Bradford (1976) method. Standards prepared with Bovine serum albumin in the range of $0.2-1.5 \mathrm{mg} / \mathrm{ml}$ with homogenization buffer were used. All analyses were performed as triplicates using 20 larvae per treatment.

\subsection{Data Evaluation}

The evaluation of the data from experiments were carried out with a statistical program (SPSS version 18.0 for Windows) and the results were shown as mean \pm standard error. Changes in means were compared using ANOVA (one-way analysis of variance) test and the differences between the groups were also determined statistically using Tukey's Least Significant Difference (LSD) tests. The results obtained at a $95 \%$ confidence interval with $\mathrm{P} \geq 0.05$ did not statistically different.

\section{Results and Discussion}

The SOD enzyme activity was found to increase approximately $22 \%$ and $46 \%$ respectively at $\mathrm{LC}_{30}$ and $\mathrm{LC}_{50}$ of dietary juglone when compared to the control group, but there was no statistically remarkable difference at $\mathrm{LC}_{10}$ juglone $(\mathrm{F}=6.77 ; \mathrm{df}=3.16 ; \mathrm{P}=0.004$; Figure 1$)$.

Concentration-dependent changes were observed in CAT activity in the hemolymph of larvae treated with the effective juglone concentrations compared to untreated larval hemolymph $(\mathrm{F}=4.283$; 
$\mathrm{df}=3,16 ; \mathrm{P}=0.021 ;$ Figure 1$)$. It was also observed that the CAT activity increased by approximately $84 \%$ at $\mathrm{LC}_{10}$ dietary juglone and by approximately $42 \%$ at the $\mathrm{LC}_{30}$ and $\mathrm{LC}_{50}$ juglone.

The activity of GST in the larval hemolymph increased by about $64 \%$ and $44 \%$ at $\mathrm{LC}_{30}$ and $\mathrm{LC}_{50}$ of dietary juglone respectively with respect to the control group $(\mathrm{F}=4.095 ; \mathrm{df}=3.16 ; \mathrm{P}=0.025$; Figure 1). Nevertheless, at $\mathrm{LC}_{10}$, there was no statistically remarkable difference in activity of GST in both the untreated, $\mathrm{LC}_{30}$ and $\mathrm{LC}_{50}$ juglone treated groups. Besides, in the enzyme activity GPx, it was determined that there were no statistically significant differences in the larval hemolymph at all concentrations of juglone and the control group $(\mathrm{F}=1.668 ; \mathrm{df}=3.16 ; \mathrm{P}=0.214$; Figure 1).

Depending on the effective concentrations of juglone added into the larval diet, the amount of MDA increased in the larval hemolymph by approximately $44 \%$ and $77 \%$, at $\mathrm{LC}_{10}$ and $\mathrm{LC}_{50}$ respectively when compared to the untreated larval hemolymph $(\mathrm{F}=3.398 ; \mathrm{df}=3.16 ; \mathrm{P}=0.044$; Figure 2). In the meantime, MDA amount in the larval hemolymph at $\mathrm{LC}_{30}$ juglone was similar to that observed in the untreated larvae.

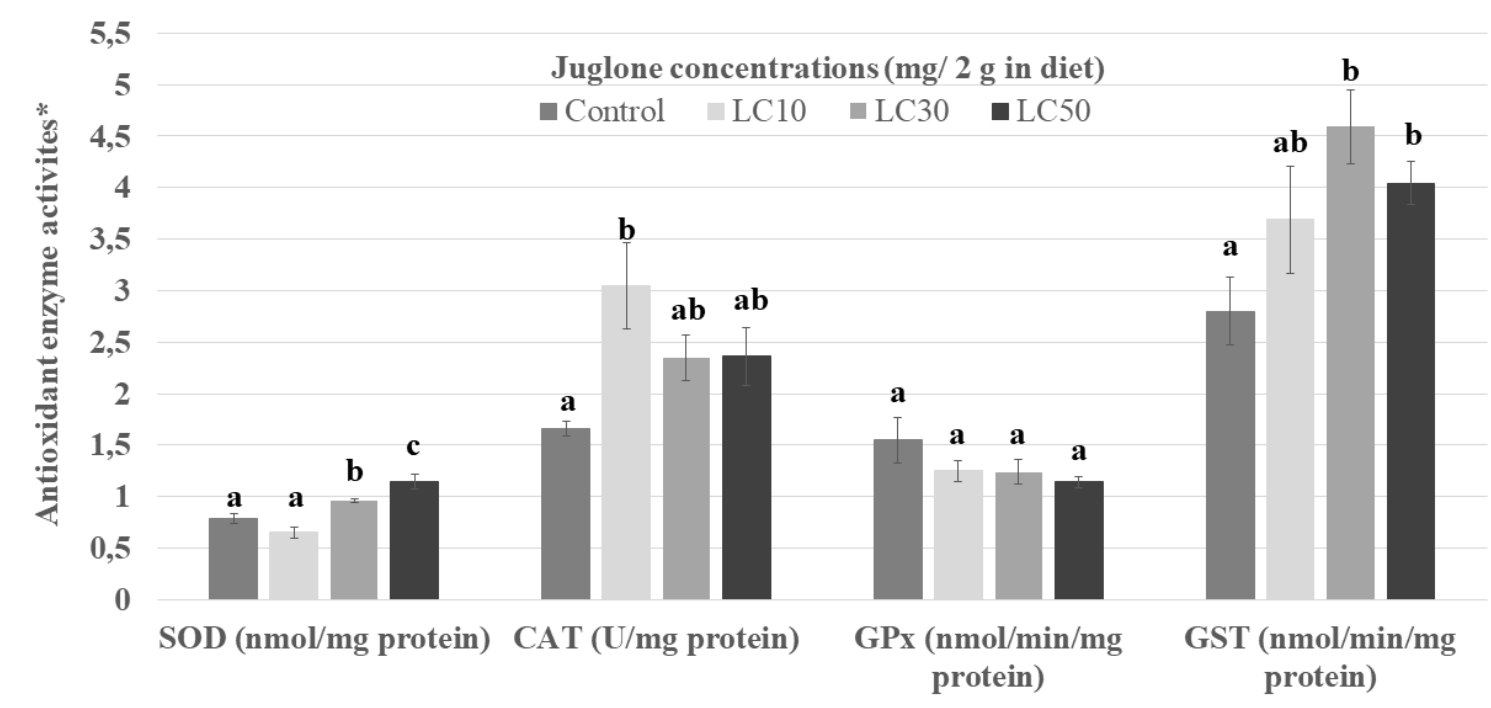

Figure 1. Differences in the antioxidant enzyme activities (SOD, CAT, GPx, and GST) in the hemolymph of last instar larvae of model insect $G$. mellonella exposed to effective concentrations $\left(\mathrm{LC}_{10}, \mathrm{LC}_{30}\right.$, and $\mathrm{LC}_{50}$ ) of dietary juglone.

* The $y$-axis refers to the mean \pm standard error (SE) values and the different letters shown in the columns represent the differences between groups ( $p<0.05$, LSD test). 


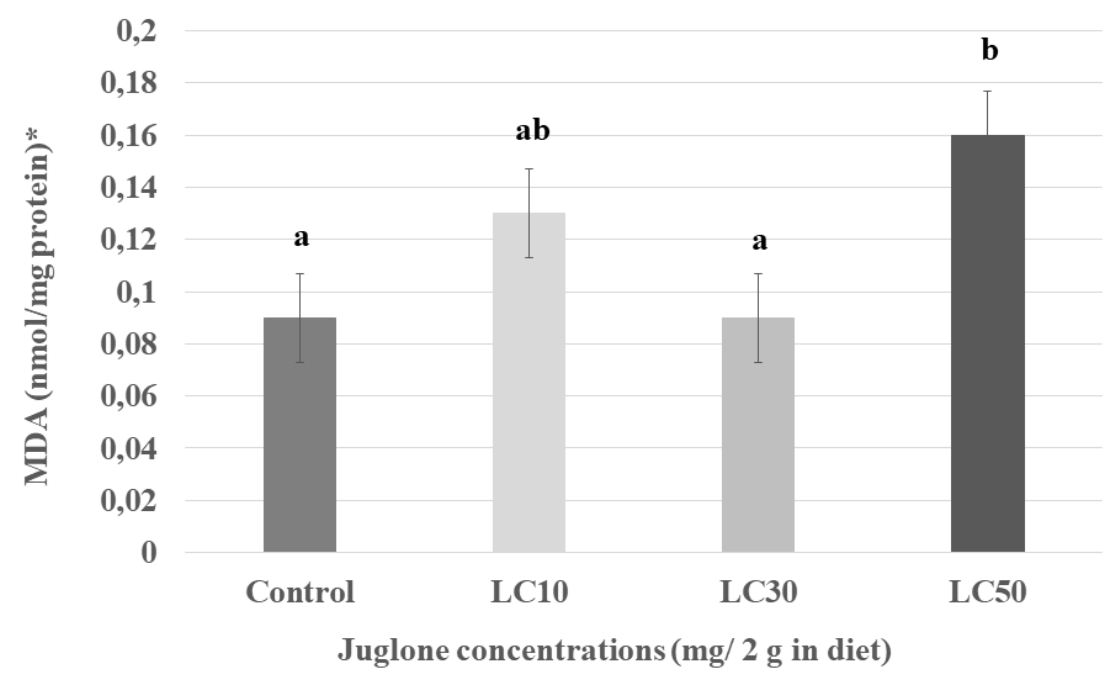

Figure 2. Differences in the MDA level in the larval hemolymph of $G$. mellonella treated with the effective concentrations $\left(\mathrm{LC}_{10}, \mathrm{LC}_{30}\right.$, and $\left.\mathrm{LC}_{50}\right)$ of dietary juglone.

* The $y$-axis refers to the mean \pm standard error (SE) values and the different letters shown in the columns represent the differences between groups ( $p<0.05$, LSD test).

Studies reported that juglone and various other naphthoquinones have negative effects on the biological properties of insects such growth, development, and reproduction (Sun et al., 2007; Sorokin and Whitaker, 2008; Hu et al., 2017; Lv et al., 2018; Altuntaş et al., 2020). It is also showed that several phenolic compounds like juglone alter the detoxification mechanism of insects (Felton et al., 1989; Felton and Duffey, 1991; Thiboldeaux et al., 1998; Felton and Summers, 1995; Krishnan and Kodrik, 2006; Altuntaş, 2015a, 2015b; Altuntaş et al., 2020;). According to previous studies, the current study showed significant variations in the antioxidant enzymes activities in the larval hemolymph of the model insect and storage pest $G$. mellonella. A significant change was observed in the SOD enzyme activity of larval hemolymph when effective concentrations of juglone, which included in the larval diet. The increased SOD activity at the $\mathrm{LC}_{30}$ and $\mathrm{LC}_{50}$ juglone concentrations could be due to juglone metabolization in the larval hemolymph which leads to the production of superoxide anion radicals (SOR) and thus activation of SOD in the juglone-treated larva occurred in hemolymph. In the larval hemolymph, SOD enzyme can increase as a phase I enzyme for the catalyzation of dismutation of SOR reactions to produce hydrogen peroxides and molecular oxygen (Sankarapandi and Zweier, 1999). Similar to our data, a recent study reported increased SOD activity in the tissue homogenate of $G$. mellonella larvae subjected to $\mathrm{LC}_{10}$ and $\mathrm{LC}_{30}$ of juglone (Altuntaş et al., 2020). The higher SOD activity observed in the larval body homogenate compared to that observed in the hemolymph at $\mathrm{LC}_{10}$ may be due to the presence of the fat body in the larval 
homogenate since detoxification of metabolic enzymes and storage proteins in insects mainly occurs in the fat body.

While SOD activity at $\mathrm{LC}_{10}$ juglone treatment reduced in the larval hemolymph the amount of MDA increased at the same concentration of juglone. The decrement in SOD activity may stem from the peroxidation of lipids in cells and the failure to remove reactive oxygen species. Besides, the damaging effects of the increase in the MDA amounts at the same concentration $\left(\mathrm{LC}_{10}\right)$ could be eliminated by an increase in CAT activity in larval hemolymph, because an increase CAT activity can reduce the sublethal oxidative damage caused by lipid peroxidation (Kazzaz et al., 1996; Tan et al., 1998). The hydrogen peroxide produced as a result of SOD activity disrupts the CAT enzyme in the second phase (Gaeta et al., 2002). Therefore, the elevation in SOD activity at $\mathrm{LC}_{30}$ and $\mathrm{LC}_{50}$ juglone may be the reason for the increase in CAT activity.

GPx activity is another parameter used to investigate the toxic effects of juglone on larval hemolymph. GPx enzyme prevents the initiation of lipid peroxidation and aids the detoxification of lipid hydroperoxides resulting from lipid peroxidation (Peric'-Mataruga et al., 1997). Data showed that GPx activity in hemolymph did not change in treated larvae with dietary juglone. This result may be related to the increase in the amount of MDA. On the other hand, it is known that while SOD activity increases due to the production of superoxide radicals, a decrease in GPx activity can occur (Gaeta et al., 2002). That's why the increase in CAT activity at $\mathrm{LC}_{10}$ and SOD activity at $\mathrm{LC}_{30}$ and $\mathrm{LC}_{50}$ concentrations of juglone could be reasons for the unchanged GPx activity in the larval hemolymph. After all, the increased activities of CAT and SOD enzymes in the last instar larval hemolymph could be relevant with an adaptive response to overcome the oxidative damage of effective juglone concentrations as it is for other xenobiotics (Krishnan and Kodrik, 2006; Aslantürk et al., 2011; Büyükgüzel et al., 2013; Altuntaş, 2015a, 2015b).

Some of allelochemicals can act as a GST substrate or GST activator in pest insects, because of this reason GST activity is a significant antioxidant enzyme in the primary detoxification metabolism of allelochemicals during the physiological response of phytophagous species (Scheline, 1978; Yu, 1982, 1987; Wadleigh and Yu, 1988). In present study, GST activity increased when the lowest concentration of dietary juglone was exposed to G. mellonella larvae, but the activity ratio remained constant as the concentration increased compared to control. In a similar study, it was reported that many allelochemical components including juglone exposed to Spodoptera frugiperda act as GST inhibitors causing inhibition of GST in the insect with increasing substrate concentration (Yu and Abo-Elghar, 2000). However, in a study conducted with Lymantria dispar (Lepidoptera), it was stated that GST, and quinine reductase enzymes take main role in the detoxification of dietary juglone and that the adaptation of the insects to their natural diet at lower doses of juglone was associated with these enzymes (Lindroth et al., 1990). In another study, activity of GST in the tissues 
of G. mellonella larvae increased at effective concentrations of juglone. This increased GST activity in larval tissue at $\mathrm{LC}_{10}$ and $\mathrm{LC}_{30}$ was interpreted as an adaptive response for the overcome of oxidative stress caused by juglone toxicity (Altuntaş et al., 2020). Besides, the same authors reported that the reason for the decreased activity of $\mathrm{GST}_{\mathrm{T}}$ at $\mathrm{LC}_{50}$ juglone could be associated with enzyme inhibition or lipid peroxidation products in the treated larval body (Altuntaş et al., 2020). Together with previous studies, induced GST activity in larval hemolymph at effective concentrations could be an adaptive physiological response employed by the insect to prevent sublethal oxidative damage induced by juglone treatment. Besides, the unchanged GST activity in the larval hemolymph at all juglone concentrations could be related to the inhibition of this enzyme by juglone. Altuntaş et al. (2020) also determined that significant damage occurred in the genome of the larvae due to the increased juglone concentration in the diets of G. mellonella. Because of this, one reason for the inhibition of GST at the sublethal doses of juglone in larval hemolymph could be related to damages in the insect's genome.

\section{Conclusions and Suggestions}

This study showed that effective concentrations of dietary juglone caused the weakening of the antioxidant defense system of $G$. mellonella larvae. This, together with findings from previous studies indicate that juglone may be used as an ecofriendly biopesticide in IPM investigations for the control of Lepidopteran insect pests. Moreover, we suggest that variations in the activities of important antioxidant enzymes and the levels of MDA can provide significant data to determine the ecotoxic properties of plant substances or secondary metabolites in insects.

\section{Acknowledgements}

This work was supported by the Scientific Research Projects Commission of Anadolu University, Turkey (Grant Number: 1608F610).

\section{Authors' Contributions}

All authors contributed equally to the study.

\section{Statement of Conflicts of Interest}

There is no conflict of interest between the authors. 


\section{Statement of Research and Publication Ethics}

The author declares that this study complies with Research and Publication Ethics.

\section{References}

Akhtar, Y., Isman, M. B., Niehaus, L. A., Lee, C. H. and Lee, H. S. (2012). Antifeedant and toxic effects of naturally occurring and synthetic quinones to the cabbage looper, Trichoplusia ni. Crop Protection, 31, $8-14$.

Altuntaş, H. (2015a). Determination of gibberellic acid (GA3)-induced oxidative stress in a model organism Galleria mellonella L. (Lepidoptera: Pyralidae). Environmental Entomology (Physiology, 44 (1), 100105.

Altuntaş, H. (2015b). Effects of ethephon on the hemolymph metabolites of the greater wax moth Galleria mellonella L. (Lepidoptera: Pyralidae). Acta Physica Polonica A, 128, 182-183.

Altuntaş, H., Duman, E. and Kılıç, G. (2020). Juglone induced oxidative and genotoxic stress in the model insect Galleria mellonella L. (Pyralidae: Lepidoptera). International Journal of Tropical Insect Science, 40, 611-619.

Altuntaş, H., Duman, E., Şanal-Demirci, S. N. and Ergin, E. (2016). Toxicological and physiological effects of ethephon on the model organism, Galleria mellonella L. 1758 (Lepidoptera: Pyralidae). Türkiye Entomoloji Dergisi, 40 (4), 413-423.

Aslantürk, A., Kalender, S., Uzunhisarcıklı, M. and Kalender, Y. (2011). Effects of methidathion on antioxidant enzyme activities and malondialdehyde level in midgut tissues of Lymantria dispar (Lepidoptera) larvae. Journal of the Entomological Research Society, 13 (3), 27-38.

Babula, P., Adam, V., Havel, L. and \& Kizek, R. (2009). Noteworthy Secondary Metabolites Naphthoquinones - their Occurrence, Pharmacological Properties and Analysis. Current Pharmaceutical Analysis, 5, 4768.

Bradford, M. M. (1976). A rapid and sensitive method for the quantitation of microgram quantities of protein utilizing the principal of protein-dye binding. Annu. Biochem., 72, 248-254.

Büyükgüzel, E., Büyükgüzel, K., Snela, M., Erdem, M., Radtke, K., Ziemnicki, K. and Adamski, Z. (2013). Effect of boric acid on antioxidant enzyme activity, lipid peroxidation and ultrastructure of midgut and fat body of Galleria mellonella. Cell Biology and Toxicology, 29, 117-129.

Büyükgüzel, E., Hyršl, P. and Büyükgüzel, K. (2010). Eicosanoids mediate hemolymph oxidative and antioxidative response in larvae of Galleria mellonella L. Comparative Biochemistry and Physiology Part A: Molecular and Integrative Physiology, 156 (2),176-183.

Cespedes, C. L., Lina-Garcia, L., Kubo, I., Salazar, J. R., Ariza-Castolo, A., Alarcon, J., Aqueveque, P., Werner, E. and Seigler, D. S. (2016). Calceolaria integrifolia s. 1. complex, reduces feeding and growth of Acanthoscelides obtectus, and Epilachna varivestis. A new source of bioactive compounds against dry bean pests. Industrial Crops \& Products, 89, 257-267.

Chance, B. and Maehly, A. C. (1955). Assay of catalase and peroxidases. Methods Enzymology, 2, 764-775.

Duman-Erbaş, E. and Altuntaş, H. (2020). Lethal and Sublethal Effects of Juglone on the Life-History Traits of Galleria mellonella L. (Lepidoptera: Pyralidae). Acta Zool. Bulg., 72 (1), 43-48.

Emam, A. M., Swelam, E. S. and Megally, N. Y. (2009). Furocoumarin and quinoloune alkaloid with larvicidal and antifeedant activities isolated from Ruta chalepensis leaves. Journal of Natural Products, 2, 10-22.

Felton, G. W. and Duffey, S. S. (1991). Protective action of midgut catalase in lepidopteran larvae against oxidative plant defenses. Journal of Chemical Ecology, 17, 1715-1732.

Felton, G. W. and Summers, C. B. (1995). Antioxidant systems in insects. Archives of Insects Biochemistry and Physiology, 29 (2), 187-197.

Felton, G. W., Donato, K. K., Del-Vecchio, R. J. and Duffey, S. S. (1989). Activation of plant foliar oxidases by insect feeding reduces nutritive quality of foliage for noctuid herbivores. Journal of Chemical Ecology, 15, 2667-2694.

Gaeta, L. M., Tozzi, G., Pastore, A., Federici, G. and Piemonte, F. (2002). Determination of superoxide dismutase and glutathione peroxidase activities in blood of healthy pediatric subjects. Clinica Chimica Acta, 322, 117-120. 
Hu, W., Du, W., Bai, S., Lv, S. and Chen, G. (2017). Phenoloxidase, an effective bioactivity target for botanical insecticide screening from green walnut husks. Nat Prod Res.

Islam, A. K. M. M. and Widhalm, J. R. (2020). Agricultural Uses of Juglone: Opportunities and Challenges. Agronomy, 10, 1500.

Jeyasankar, A., Raja, N. and Ignacimuthu, S. (2010). Antifeedant and growth inhibitory activities of Syzygium lineare Wall (Myrtaceae) against Spodoptera litura Fab (Lepidoptera: Noctuidae). Current Research Journal of Biological Sciences, 2 (3), 173-177.

Kazzaz, J. A., Xu, J., Palaia, T. A., Mantell, L., Fein, A. M. and Stuart-Horowitz, S. (1996). Cellular Oxygen Toxicity. The Journal of Biological Chemistry, 271 (25), 15182-15186.

Krishnan, N. and Kodrik, D. (2006). Antioxidant enzymes in Spodoptera littoralis (Boisduval): Are they enhanced to protect gut tissues during oxidative stres. Journal of Insect Physiology, 52, 11-20.

Lee, K. (1991). Glutathione S-transferase activities in phytophagous insects: Induction and inhibition by plant phototoxins and phenols. Insect Biochemistry, 21, 353.

Lindroth, R. L., Anson, B. D. and Weisbrod, A. V. (1990). Effects of protein and Juglone on Gypsy moths: Growth performance and detoxification enzyme activity. Journal of Chemical Ecology, 16 (8), 25332547.

Lv, S. T., Du, X., Bai, S. M. and Chen, G. (2018). Insecticidal effect of juglone and its disturbance analysis in metabolic profiles of Aphis gossypii glover using $1 \mathrm{H}$ NMR-based metabonomics approach. Phytoparasitica, 46, 521-531.

Paul, D. and Sohkhlet, M. D. (2012). Anti-feedant, repellent and growth regulatory effects of four plants extracts on Pieris brassiceae larvae (Lepidoptera: Pieridae). Open Access Scientific Reports, 1 (10), 1 5.

Peric'-Mataruga, V., Blagojevic, D., Spasic, M. B., Ivanovic, J. and Jankovic-Hladni, M. (1997). Effect of the host plant on the antioxidative defence in the midgut of Lymantria dispar L. caterpillars of different population origins. Journal of Insect Physiology, 43, 101-106.

Piskorski, R., Ineichen, S. and Dorn, S. (2011). Ability of the oriental fruit moth Grapholita molesta (Lepidoptera: Tortricidae) to detoxify Juglone, the main secondary metabolite of the non-host plant walnut. Journal of Chemical Ecology, 37, 1110-1116.

Rattan, R. S. and Sharma, A. (2011). Plant secondary metabolites in the sustainable diamondback moth (Plutella xylostella L.) management. Indian Journal of Fundamental and Applied Life Sciences, 1 (3), 295-309.

Sankarapandi, S. and Zweier, J. L. (1999). Evidence against the Generation of Free Hydroxyl Radicals from the Interaction of Copper, Zinc-Superoxide Dismutase and Hydrogen Peroxide. The Journal of Biological Chemistry, 274 (49), 34576-34583.

Scheline, R. R. (1978). Mammalian metabolism of plant xenobitics. Academic Press, New York.

Sezer-Tuncsoy, B., Tuncsoy, M., Gomes, T., Sousa, V., Teixeira, M. R., Bebianno, M. J. and Ozalp, P. (2019). Effects of Copper Oxide Nanoparticles on Tissue Accumulation and Antioxidant Enzymes of Galleria mellonella L. Bulletin of Environmental Contamination and Toxicology, 102, 341-346.

Sorokin, N. and Whitaker, J. (2008). The impacts of selected natural plant chemicals on terrestrial invertebrates. Secondary Metabolites in Soil Ecology Chapter 12 (Ed) Karlovsky P, Berlin, Springer.

Sun, M., Wang, Y., Song, Z. and Fang, G. (2007). Insecticidal activities and active components of the alcohol extract from green peel of Juglans mandshurica. Journal of Forestry Research, 18, 62-64.

Şeref-Gün, S., Çinbilgel, İ., Öz, E. and Çetin, H. (2011). Bazı Salvia L. (Labiatae) bitki ekstraktlarının, sivrisinek Culex pipiens L. (Diptera: Culicidae)'e karşı larva öldürücü aktivitesi. Kafkas Üniversitesi Veterinerlik Fakültesi Dergisi, 17 (Suppl A), 61-65.

Tan, S., Sagara, Y., Liu, Y., Maher, P. and Schubert, D. (1998). The Regulation of Reactive Oxygen Species Production during Programmed Cell Death. The Journal of Cell Biology, 141, 1423-1432.

Thiboldeaux, R. L., Lindroth, R. L. and Tracy, J. W. (1994). Differential toxicity of juglone (5-hydroxy-1,4naphthoquinone) and related naphthoquinones to Saturniid moths. Journal of Chemical Ecology, 20, 1631-1641.

Thiboldeaux, R. L., Lindroth, R. L. and Tracy, J. W. (1998). Effects of juglone (5-hydroxy-1,4naphthoquinone) on midgut morphology and glutathione status in Saturniid moth larvae. Comparative Biochemistry and Physiology, 120, 481-487.

Wadleigh, R. W. and Yu, S. J. (1988). Detoxcification of 1sothiocyanate allelochemicals by glutathione transferase in three lepidopteraus species. Journal of Chemical Ecology, 14, 1279-1288.

Wheeler, G. S., Slansky, F. and Yu, S. J. (1993). Fall armyworm sensitivity to flavone: Limited role of constitutive and induced detoxifying enzyme activity. Journal of Chemical Ecology, 19, 645. 
$\mathrm{Yu}$, S. J. (1982). Host plant induction of glutathione-S-transferase in the faal armyworm. Pesticide Biochemistry and Physiology, 18, 101-106.

$\mathrm{Yu}$, S. J. (1987). Quinone reductase of phytophagous insects and its induction by allelochcmicals. Comparative Biochemistry and Physiology, 87B, 621-624.

Yu, S. J. and Abo-Elghar, G. E. (2000). Allelochemicals as Inhibitors of Glutathione S-Transferases in the Fall Armyworm. Pesticide Biochemistry and Physiology, 68, 173-183.

Yu, S. J. and Huang, S. W. (2000). Purification and characterization of glutathione S-transferases from the German cockroach, Blattella germanica (L.). Pesticide Biochemistry and Physiology, 67, 36. 